\title{
Lama Post Operasi Coronary Artery Bypass Graft (CABG) dengan Kualitas Hidup Pasien Post Operasi CABG Di RSPAD Gatot Soebroto
}

\author{
Titik Suyanti ${ }^{1}$, Sri Rahayu ${ }^{2}$ \\ ${ }^{1}$ Mahasiswa Prodi Sarjana Keperawatan, STIKes Jayakarta, Yayasan PKP DKI Jakarta \\ ${ }^{2}$ Program Studi Sarjana Keperawatan, STIKes Jayakarta, Yayasan PKP DKI Jakarta \\ e-mail: srirahayu1903@gmail.com
}

Submitted : 14/02/2020

Accepted: $28 / 02 / 2020$

Published: 07/09/2020

\begin{abstract}
Coronary heart disease (CHD) can be treated with Coronary Artery Bypass Graft (CABG). This procedure is expected to reduce the morbidity and mortality rates due to CHD, and able to improve the quality of life. However, the recovery time of patients with post-operative CABG requires time to achieve a better quality of life. This study aims to determine the relationship between the length of postoperative $C A B G$ with the quality of life of post-operative CABG patients in Gatot Soebroto Army Hospital. The research method used a descriptive quantitative with a cross-sectional approach with a sample of 31 post-operative $C A B G$ patients who were willing to be respondents. Total sampling was used in this study. The instrument used a WHOQOL-BREF questionnaire that was valid and reliable. The results showed that the characteristics of patients with post-operative CABG were mostly 14 people (45.2\%) aged 50-59 years old, 25 people (80.6\%) were male, 16 people (51, 6\%) were high school, and 15 people (48.4\%) not working, 15 people (48.4\%) have a length of post-operative CABG 4-6 months, and 21 people (67.7\%) have a good quality of life. The results of the bivariate analysis with the Chi-square test showed that there was a relationship between the length of postoperative CABG with the quality of life of patients with a p-value = 0.006. The conclusion is encouraging the patients, families, and health workers, especially nurses have to pay attention to the quality of life of patients based on the length of post-operative CABG. Because of the length of post-operative CABG the better the quality of life of patients.
\end{abstract}

Keywords: $C A B G$, length of post-operative, quality of life

\begin{abstract}
Abstrak
Penyakit Jantung koroner (PJK) dapat ditangani dengan salah satu tindakan yang bernama Coronary Artery Bypass Graft (CABG). Tindakan ini diharapkan dapat menekan angka morbiditas dan mortilitas karena PJK, serta mampu meningkatkan kualitas hidup pasien. Akan tetapi, pemulihan pasien post operasi CABG memerlukan waktu untuk mencapai kualitas hidup yang lebih baik. Penelitian ini bertujuan untuk mengetahui hubungan lama post operasi CABG dengan kualitas hidup pasien post operasi CABG di RSPAD Gatot Soebroto. Metode penelitian yang digunakan adalah deskriptif kuantitatif dengan pendekatan cross-sectional dengan sampel sebanyak 31 pasien post operasi CABG yang bersedia menjadi responden. Pengambilan sampel dengan cara total sampling. Instrumen yang digunakan dalam penelitian ini adalah kuesioner WHOQOL-BREF yang sudah valid dan reliabel. Hasil penelitian menunjukkan bahwa karakteristik pasien post operasi CABG adalah sebagian besar berusia 50-59 tahun sebanyak 14 orang (45,2\%), berjenis kelamin laki-laki sebanyak 25 orang $(80,6 \%)$, berpendidikan SMA sebanyak 16 orang $(51,6 \%)$, dan tidak bekerja sebanyak 15 orang $(48,4 \%)$, memiliki lama post operasi CABG $4-6$ bulan sebanyak 15 orang $(48,4 \%)$, dan sebanyak 21 orang $(67,7 \%)$ memiliki kualitas hidup baik. Hasil analisa bivariat dengan uji Chi-square menunjukkan bahwa ada hubungan antara lama post operasi CABG dengan kualitas hidup pasien dengan nilai $p$-value $=0,006$. Kesimpulannya yaitu mendorong pasien, keluarga, dan petugas kesehatan terutama perawat perlu memperhatikan kualitas hidup pasien berdasarkan lama post operasi. Mengingat semakin lama post operasi CABG semakin baik kualitas hidup pasien.
\end{abstract}

Kata Kunci : $C A B G$, kualitas hidup, lama post operasi 


\section{PENDAHULUAN}

Negara Indonesia mengalami peningkatan kasus dengan penyakit kardiovaskular. Salah satunya adalah penyakit jantung koroner (PJK). PJK terjadi karena adanya penyumbatan atau penyempitan pada pembuluh darah koroner yang menyebabkan aliran darah ke jantung terbatas (American Heart Association (AHA), 2019). Data dari World Health Organization (WHO) (2014a) menunjukkan bahwa PJK merupakan penyebab kematian pertama di dunia sejak tahun 2000 hingga tahun 2015. Sedangkan di Indonesia, PJK merupakan penyebab kematian nomor dua dengan jumlah kematian sebanyak 138.400 orang (Biro Komunikasi dan Pelayanan Masyarakat, 2017; WHO, 2014a). Salah satu penanganan PJK adalah dengan tindakan Coronary Artery Bypass Graft (CABG).

Kejadian PJK juga terus mengalami peningkatan setiap tahunnya di RSPAD Gatot Soebroto Jakarta. Data yang diperoleh dari poliklinik jantung RSPAD Gatot Soebroto Jakarta mencapai 1500 orang penderita PJK dan 50 orang diantaranya malakukan prosedur operasi Coronary Artery Bypass Graft (CABG) di tahun 2017, sedangkan di tahun 2018 ada 2000 orang penderita PJK dan 67 pasien yang melakukan prosedur operasi CABG dan kurang lebih ada 30 pasien yang melakukan kontrol rutin ke poliklinik jantung RSPAD Gatot Soebroto Jakarta setiap bulannya. Jumlah pasien yang datang kontrol setelah operasi CABG di RSPAD cenderung menurun, karena pada umumnya pasien kembali ke daerah masing-masing karena pasien tersebut merupakan pasien rujukan dari daerah. Sehingga pasien melanjutkan terapi di daerahnya masingmasing ketika kondisi kesehatannya mulai membaik.

Kualitas hidup pasien dengan PJK mengalami peningkatan setelah menjalankan operasi CABG. Hal ini dibuktikan dengan hasil penelitian yang dilakukan Aziza (2013) yang menjelaskan bahwa pasien post CABG mengalami perubahan dalam memandang kualitas hidupnya yang sekarang menjadi puas karena merasa lebih baik dibandingkan dengan sebelum menjalankan prosedur operasi CABG. Pasien post operasi CABG juga memandang kualitas hidupnya meningkat dari berbagai aspek, seperti fisik, keluarga, dan lingkungan pekerjaan. Selain itu, penelitian yang dilakukan oleh Rosidawati (2016) menyatakan bahwa kualitas hidup pada pasien post CABG lebih baik dari sebelum dilakukan operasi. Akan tetapi belum ada yang menganalisa lebih mendalam tentang kualitas hidup pasien menjadi lebih baik di bulan ke berapa setelah operasi CABG.

Beberapa penjelasan diatas, maka dapat disimpulkan bahwa CABG dapat mempengaruhi kualitas hidup pasien yang menjalaninya. Namun perlu dikaji lebih dalam lama waktu yang dilalui pasien setelah dilakukan tindakan operasi CABG apakah berhubungan dalam kualitas hidupnya. Sehingga tujuan dari penelitian ini adalah untuk mengetahui hubungan lama post operasi CABG dengan kualitas hidup pasien post operasi CABG di RSPAD Gatot Soebroto.

\section{METODE PENELITIAN}

Penelitian ini merupakan jenis penelitian kuantitatif dengan metode deskriptif korelasional yaitu penelitian yang bertujuan untuk melihat hubungan antara variabel independen lama post operasi CABG dengan variabel dependen kualitas hidup pasien post operasi CABG. Penelitian ini dilakukan pada bulan Maret-Juni 2019. Tempat dilakukannya penelitian yaitu di poliklinik rawat jalan termasuk didalamnya poliklinik bedah jantung, poliklinik jantung, dan poliklinik penyakit dalam RSPAD Gatot Soebroto, Jakarta Pusat. Target populasinya adalah pasien post operasi CABG yang kontrol ke poliklinik rawat jalan pada bulan Maret-Juni 2019 di RSPAD Gatot Soebroto Jakarta. Teknik pengambilan sampel dengan cara total 
sampling dan sejumlah 31 pasien post operasi bersedia menjadi responden. Kriteria inklusinya yaitu Pasien minimal 1 (satu) bulan post operasi CABG yang kontrol ke poliklinik rawat jalan di RSPAD Gatot Soebroto, dan pasien post operasi CABG dengan kondisi atau keadaan umum stabil. Sedangkan kriteria eklusinya yaitu pasien post operasi CABG yang masih menjalani perawatan di ruang rawat inap RSPAD Gatot Soebroto, dan yang tidak bersedia menjadi responden.

Metode pengumpulan data yaitu menggunakan kuesioner yang terdiri dari data demografi, lama post operasi CABG, dan kualitas hidup. Kuesioner kualitas hidup menggunakan kuesioner baku yaitu WHOQOL-BREF (WHO), 2014b) yang memiliki 26 pertanyaan dengan skala Likert. Kuesioner ini terdiri dari 4 domain kualitas hidup yaitu domain fisik, psikologis, hubungan sosial, dan lingkungan. Pertanyaan nomor 1 dan 2 pada kuesioner mengkaji tentang kualitas hidup secara menyeluruh dan kesehatan secara umum. Domain 1-Fisik terdapat pada pertanyaan nomor 3, 4, 10, 15, 16, 17, dan 18. Domain 2-Psikologis ada pada pertanyaan nomor 5, 6, 7, 11, 19, dan 26. Domain 3-Hubungan sosial ada pada pertanyaan nomor 20, 21, dan 22. Domain 4-Lingkungan ada pada pertanyaan nomor $8,9,12,13,14,23,24$, dan 25. Instrumen ini juga terdiri atas pertanyaan positif, kecuali pada tiga pertanyaan yaitu nomor 3, 4, dan 26 yang bernilai negatif. Pada penelitian ini skor tiap domain (raw score) ditransformasikan dalam skala 0-100 (Koesmanto, S., \& Novandhori, 2013). Semakin tinggi skor yang didapat semakin baik/tinggi kualitas hidup pasien dan apabila skor yang didapat semakin rendah maka semakin buruk/rendah kualitas hidup pasien.

\section{HASIL DAN PEMBAHASAN}

\section{Analisa Univariat \\ Karakteristik Pasien}

Tabel 1. Distribusi frekuensi karakteritik pasien post operasi CABG di RSPAD Gatoto Soebroto (N=31)

\begin{tabular}{lcc}
\hline Karakteristik Pasien & Frekuensi & $\begin{array}{c}\text { Persentase } \\
(\%)\end{array}$ \\
\hline Usia & & \\
$\quad<39$ tahun & 1 & 3,2 \\
$40-49$ tahun & 3 & 9,7 \\
$50-59$ tahun & 14 & 45,2 \\
$>60$ tahun & 13 & 41,9 \\
Jenis Kelamin & & \\
Laki-laki & 25 & 80,6 \\
Perempuan & 6 & 19,4 \\
Pendidikan Terakhir & & \\
SMA & 16 & 51,6 \\
Perguruan Tinggi & 15 & 48,4 \\
Pekerjaan & & \\
TNI/Polri & 6 & 19,4 \\
PNS & 3 & 9,7 \\
Swasta & 5 & 16,1 \\
Ibu Rumah Tangga & 2 & 6,5 \\
Tidak Bekerja & 15 & 48,4 \\
\hline$\quad$ Pada tabel 1 ment
\end{tabular}

Pada tabel 1 menunjukkan bahwa dari 31 pasien post operasi CABG, sebagian besar berusia 50-59 tahun sebanyak 14 orang $(45,2 \%)$, berjenis kelamin laki-laki sebanyak 25 orang $(80,6 \%)$, berpendidikan SMA sebanyak 16 orang $(51,6 \%)$, dan tidak bekerja yaitu sebanyak 15 orang $(48,4 \%)$.

Rata-rata usia pasien PJK dengan post operasi CABG di Poliklinik Rawat Jalan RSPAD Gatot Soebroto lebih banyak di rentang usia 50-59 tahun (45,2\%). Tertinggi kedua pada usia lebih dari 60 tahun dengan persentase sebesar 41,9\%. Usia yang hampir sama juga ditemukan pada penelitian lain yaitu usia 56-65 tahun $(44,73 \%)$ oleh Wulandari (2017) dan usia 45-64 tahun (80\%) oleh Ginting (2017). Hal ini menunjukkan bahwa usia pasien PJK berada pada rentang usia dewasa akhir hingga lansia. Rentang usia ini merupakan rentang usia berisiko mengalami berbagai macam penyakit, termasuk PJK karena faktor usia.

Pada penelitian ini pasien PJK dengan post operasi CABG berjenis kelamin lakilaki sebanyak 25 orang $(80,6 \%)$. Hasil ini 
sejalan dengan hasil penelitian lain yang menyebutkan bahwa pasien post CABG berjenis kelamin laki-laki $(92,10 \%)$ oleh Wulandari (2017) dan 84,3\% oleh Ginting (2017). Hal ini menjelaskan bahwa laki-laki memiliki risiko PJK yang lebih tinggi dibandingkan dengan perempuan. Selain itu, laki-laki cenderung merokok, sehingga beresiko untuk terkena penyakit jantung (Black, J. M., \& Hawks, 2014). Ini dikuatkan oleh penelitian Wulandari (2017) yang menyebutkan $92.10 \%$ pasien post CABG memiliki riwayat sebagai perokok.

Tingkat pendidikan pasien terbanyak dengan tingkat pendidikan SMA sebanyak 16 orang $(51,6 \%)$. Tingkat pendidikan ini hanya beda sedikit dengan pasien PJK dengan post operasi CABG yang memiliki tingkat pendidikan perguruan tinggi, yaitu sebanyak 15 orang $(48,4 \%)$. Pada penelitian ini tidak didapatkan pasien dengan PJK yang memiliki tingkat pendidikan SD hingga SMP. Hal ini dapat diartikan bahwa pasien PJK dengan post operasi CABG dalam penelitian termasuk memiliki pengetahuan yang cukup tentang informasi kesehatan. Kemungkinan ada faktor lain yang menyebabkan penyakit ini.

Pasien dalam penelitian ini lebih didominasi dengan tidak bekerja sebanyak 15 orang $(48,4 \%)$. Hal ini dapat disebabkan karena lebih banyak pasien diatas umur 50 tahun yang datang berobat sehingga sudah memasuki usia pensiun.

\section{Lama Post Operasi CABG}

Tabel 2. Distribusi frekuensi lama post operasi CABG di RSPAD Gatoto Soebroto $(\mathrm{N}=31)$

\begin{tabular}{ccc}
\hline Lama Post Operasi & Frekuensi & $\begin{array}{c}\text { Persentase } \\
(\%)\end{array}$ \\
\hline <ABG & & 9,7 \\
4 bulan 6 bulan & 3 & 48,4 \\
$>$ 6 bulan & 15 & 41,9 \\
\hline Total & 13 & 100 \\
\hline
\end{tabular}

Pada table 2 menunjukkan bahwa dari 31 pasien post operasi CABG memiliki lama post operasi CABG $4-6$ bulan sebanyak 15 orang $(48,4 \%)$, lama post $\mathrm{CABG}>6$ bulan sebanyak 13 orang $(41,9 \%)$ dan lama post $\mathrm{CABG}<4$ bulan sebanyak 3 orang $(9,7 \%)$.

\section{Kualitas Hidup Pasien Post Operasi CABG}

Tabel 3. Distribusi frekuensi kualitas hidup pasien post operasi CABG di RSPAD Gatoto Soebroto $(\mathrm{N}=31)$

\begin{tabular}{ccc}
\hline Variabel Dependen & Frekuensi & $\begin{array}{c}\text { Persentase } \\
(\%)\end{array}$ \\
\hline Kualitas Hidup & & \\
\hline Kurang & 3 & 9,7 \\
Cukup & 7 & 22,6 \\
Baik & 21 & 67,7 \\
\hline Domain Fisik & \\
\hline Kurang & 6 & 19,4 \\
Cukup & 6 & 19,4 \\
Baik & 19 & 61,3 \\
\hline Domain Psikologis & & \\
\hline Kurang & 2 & 6,5 \\
Cukup & 19 & 61,3 \\
Baik & 10 & 32,3 \\
\hline Domain Hubungan Sosial & & 9,7 \\
\hline Kurang & 3 & 61,3 \\
Cukup & 19 & 29,0 \\
Baik & 9 & \\
\hline Domain Lingkungan & & 12,9 \\
\hline Kurang & 4 & 19,4 \\
Cukup & 6 & 67,7 \\
Baik & 21 &
\end{tabular}

Pada tabel 3 menunjukkan bahwa 31 pasien post operasi CABG, mayoritas memiliki kualitas hidup baik yaitu sebanyak 21 orang $(67,7 \%)$. Sedangkan untuk domain kualitas hidup adalah mayoritas memiliki kualitas hidup domain fisik baik yaitu sebanyak 19 orang $(61,3 \%)$, domain psikologis cukup sebanyak 19 orang (61,3\%), domain hubungan sosial cukup sebanyak 19 orang (61,3\%), domain lingkungan responden baik yaitu sebanyak 21 orang $(67,7 \%)$. Pada penelitian ini menunjukkan bahwa lama post operasi CABG sebagian besar di rentang 4-6 bulan sebanyak 15 pasien $(48,4 \%)$. Rentang 4-6 bulan termasuk ke dalam fase pemulihan dengan tujuan untuk mencapai tingkat aktivitas secara maksimal, program perubahan gaya hidup jangka panjang seperti program latihan, diet, dan manajemen stress (Williams, L. S., \& Hopper, 2007). Sedangkan sebanyak 3 
orang $(9,7 \%)$ pasien PJK post operasi CABG kurang dari 4 bulan termasuk dalam fase awal, yaitu dipusatkan pada pencapaian atau pemeliharaan stabilitas hemodinamik, pemulihan anestesi umum, perawatan luka, pencegahan edema dengan memakai stocking (compression stocking) setiap hari selama 4-6 minggu pertama dan mengelevasikan kaki jika duduk (AlizadehGhavidel, A., Ramezannejad, P., Mirmesdagh, Y., \& Sadeghpour-Tabae, 3AD; Lewis, S. L., Dirksen, S. R., Heitkemper, M. M., \& Bucher, 2014). Selain itu, melihat kemajuan aktivitas dan diet, dan juga memberikan pendidikan kesehatan tentang pengobatan dan modifikasi faktor risiko. Selama pemulihan pada bulan kedua dan ketiga berfokus kepada kegiatan kerja dan kembalinya aktivitas sosial dan seksual (Lewis, S. L., Dirksen, S. R., Heitkemper, M. M., \& Bucher, 2014).

Kualitas hidup adalah persepsi individu terkait evaluasi dalam aspek positif maupun negatif dari kehidupan yang dipengaruhi oleh budaya dan sistem nilai dilingkungannya WHO (2014b). Hasil penelitian ini menunjukkan bahwa mayoritas pasien memiliki kualitas hidup baik sebanyak $67,7 \%$. Beberapa penelitian sejalan dengan hasil penelitian ini yang menjelaskan bahwa kualitas hidup pasien post operasi $\mathrm{CABG}$ meningkat jika dibandingkan dengan sebelum operasi (Atapattu, P. M., \& Warnasooriya, 2016).

Pada domain fisik kualitas hidup didapatkan bahwa sebagian besar pasien PJK post operasi CABG memiliki kualitas hidup baik sebanyak 19 orang $(61,3 \%)$. Hal yang sama juga ditemukan pada penelitian lain yang menyebutkan adanya peningkatan kualitas hidup pada domain fisik (Hutagalung, R. U., Susilaningsih, F. S., \& Mardiyah, 2014). Kualitas hidup tersebut meningkat karena peranan perawat dalam membantu pasien post operasi CABG untuk mencapai kualitas hidup yang optimal, dengan cara peningkatan efikasi diri pasien melalui pendampingan dan pemberian informasi dan edukasi (Hutagalung, R. U., Susilaningsih, F. S., \& Mardiyah, 2014).

Pada domain psikologis, sebagian besar pasien memiliki kualitas hidup cukup sebanyak 19 orang (61,3\%). Hasil ini sejalan dengan penelitian (Hutagalung, R. U., Susilaningsih, F. S., \& Mardiyah, 2014). Rasa cemas yang dirasakan oleh pasien post CABG dapat disebabkan oleh program rehabilitasi yang harus dijalani. Hasil penelitian menunjukkan bahwa kecemasan berhubungan dengan kualitas hidup (Awaludin, S., Afni, A. C. N., Sekarwati, 2018).

Pada domain hubungan sosial, kualitas hidup baik pada pasien PJK post operasi CABG didapatkan sebagian besar yaitu 19 orang $(61,3 \%)$ memiliki kualitas hidup cukup. Hasil ini sejalan dengan penelitian (Hutagalung, R. U., Susilaningsih, F. S., \& Mardiyah, 2014). Peningkatan kualitas hidup pasien juga diperoleh karena adanya dukungan keluarga dan sosial. Hal ini sesuai karena pasien adalah makhluk sosial yang membutuhkan orang lain untuk menjalani kehidupannya. Bentuk dukungan sosial yang didapat pasien post CABG adalah emotional support yang diberikan keluarga.

Pada domain lingkungan, sebagian pasien post $\mathrm{CABG}$ sebanyak 21 orang $(67,7 \%)$ memiliki kualitas hidup baik. Hal ini didukung oleh penelitian Aziza (2013) yang menyatakan puas dengan lingkungan.

\section{Analisa Bivariat}

Pada tabel 4 menunjukkan bahwa pasien yang lama post operasi CABG $<4$ bulan memiliki kualitas hidup kurang sebanyak 2 orang $(66,7 \%)$, pasien yang lama post CABG $4-6$ bulan memiliki kualitas hidup hidup baik sebanyak 10 orang $(66,7 \%)$, dan pasien yang lama post CABG $>6$ bulan memiliki kualitas hidup baik sebanyak 11 orang $(84,6 \%)$. 
Tabel 4. Hubungan lama post operasi CABG dengan kualitas hidup pasien post operasi CABG di RSPAD Gatoto Soebroto (N=31)

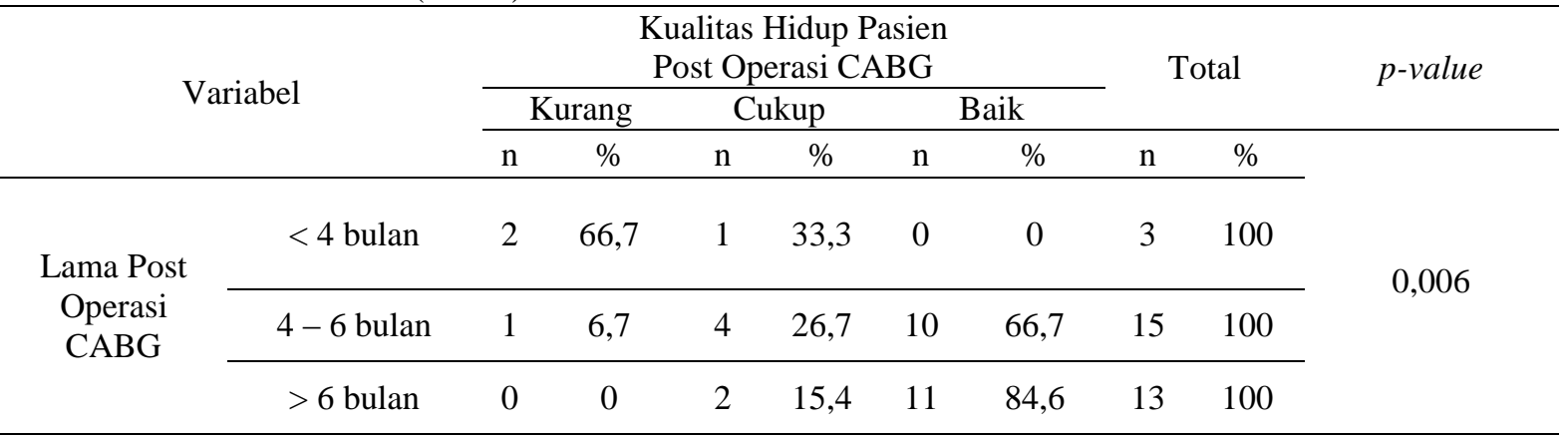

Hasil uji statistik dengan menggunakan uji chi-square diperoleh nilai signifikan atau $p$-value adalah $0,006(\mathrm{p}<$ $0,05)$ sehingga dapat disimpulkan bahwa adanya hubungan antara lama post operasi CABG dengan kualitas hidup pasien di poliklinik rawat jalan RSPAD Gatot Soebroto Jakarta.

Hasil penelitian menunjukkan bahwa lama post $\mathrm{CABG}>6$ bulan memiliki kualitas hidup baik sebanyak 11 pasien $(84,5 \%)$, dan lama post operasi < 4 bulan memiliki kualitas hidup yang kurang yaitu sebanyak 2 orang $(66,7 \%)$. Hasil penelitian menjelaskan bahwa kualitas hidup pasien post operasi CABG akan meningkat dalam tiga bulan dalam hal kesehatan fisik (Bonaros, N., Schachner, T., Wiedemann, D., Oehlinger, A., Ruetzler, E., Feutchner, G., . . Bonatti, 2008). Peningkatan kualitas hidup pasien post operasi CABG ditemukan paling tinggi yaitu lebih dari 6 bulan setelah dilakukannya operasi CABG (Peric, V., Jovanovic-Markovic, S., Peric, D., Rasic, D., Novakovic, T., Dejanovic, B., \& Borzanovic, 2015).

Hasil uji bivariat dengan menggunakan uji Chi-square menunjukkan adanya hubungan antara lama post operasi CABG dengan kualitas hidup pasien post operasi CABG di RSPAD Gatot Soebroto dengan nilai $p$-value $0,006(\mathrm{p}<0,05)$. Hal ini menjelaskan bahwa semakin lama post operasi $\mathrm{CABG}$, maka semakin baik tingkat kualitas hidupnya. Demikian juga sebaliknya, semakin baru post operasi
CABG, maka semakin kurang kualitas hidupnya.

\section{SIMPULAN}

Pada penelitian ini ditemukan beberapa hasil penelitian yang unik dan sangat menarik, yaitu; Karakteristik pasien post CABG yaitu rata-rata usia pasien pada rentang 50-59 tahun, berjenis kelamin lakilaki, memiliki tingkat pendidikan antara pendidikan menengah keatas sampai perguruan tinggi, dan tidak bekerja. Lama post operasi CABG yaitu antara 4-6 bulan. Kualitas hidup pasien post operasi CABG yaitu sebagian besar memiliki kualitas hidup baik. Adanya hubungan antara lama post operasi $\mathrm{CABG}$ dengan kualitas hidup pasien post operasi CABG di RSPAD Gatot Soebroto.

Hasil penelitian ini diharapkan dapat dijadikan sebagai bahan kajian pembelajaran, sumber informasi, dan perkembangan ilmu pengetahuan. Selain itu, diharapkan hasil penelitian dapat dijadikan sebagai acuan dan media edukasi bagi perawat, pasien, dan keluarganya untuk lebih memperhatikan perkembangan pemulihan kesehatan dan kualitas hidup pasien post operasi CABG pada setiap program rehabilitasinya mulai dari hari, minggu, bulan, bahkan tahun. Semoga penelitian ini dapat dilanjutkan oleh peneliti lainnya untuk lebih melihat ke depan kualitas hidup pasien sampai beberapa tahun.

\section{DAFTAR PUSTAKA}

Alizadeh-Ghavidel, A., Ramezannejad, P., 
Mirmesdagh, Y., \& SadeghpourTabae, A. (3AD) 'Prevention of edema after coronary artery bypass graft surgery by compression stocking', Research Cardiovascular Medicine, 2, pp. 1-5. doi: 10.5812/cardiovascmed.17463.

American Heart Association (AHA) (2019) Coronary artery disease-coronary heart disease. Available at: https://www.heart.org/en/healthtopics/consumer-healthcare/what-iscardiovascular-disease/coronaryartery-disease.

Atapattu, P. M., \& Warnasooriya, W. M. (2016) 'Quality of life before and after coronary artery bypass grafting: Findings among pre-operative and post-operative patients at the National Hospital of Sri Lanka.', Journal of the Ceylon College of Physicians, pp. 9297.

doi: http://doi.org/10.4038/jccp.v47i2.779 0 .

Awaludin, S., Afni, A. C. N., Sekarwati, W. (2018) 'Hubungan kecemasan dengan kualitas hidup pasien post coronary artery baypass graft (CABG) di Ruang Rehabilitasi Jantung Rumah Sakit Jantung dan Pembuluh Darah Harapan Kita Jakarta', Jurnal Kesehatan Kusuma Husada, pp. 243 247.

Aziza, W. (2013) 'Kualitas hidup pasien post cabg (coronary artery bypass graft) suatu studi fenomenologi. Ambon: Prosiding FMIPA Universitas Patimura', in.

Biro Komunikasi dan Pelayanan Masyarakat (2017) Penyakit jantung penyebab kematian tertinggi, Kemenkes ingatkan CERDIK, Jakarta: Departemen Kesehatan. Available at: www.depkes.go.id/ article/ print/17073100005/ penyakit-jantungpenyebabkematian- tertinggikemenkes-ingatkan-cerdik-.html (Accessed: 10 April 2018).

Black, J. M., \& Hawks, J. H. (2014)
Keperawatan medikal bedah: Manajemen klinis untuk hasil yang diharapkan (Vol. III). Singapura: Elsevier.

Bonaros, N., Schachner, T., Wiedemann, D., Oehlinger, A., Ruetzler, E., Feutchner, G., . . . Bonatti, J. (2008) 'Quality of life improvement after robotically assisted coronary artery bypass grafting', Cardiology, pp. 59-66. doi: doi:10.1159/000212115.

Ginting, A. D. B. (2017) 'Karakteristik pasien penyakit jantung koroner yang dilakukan coronary artery bypass graft di Rumah Sakit Umum Pusat Haji Adam Malik Medan pada tahun 2015-2016'.

Hutagalung, R. U., Susilaningsih, F. S., \& Mardiyah, A. I. (2014) 'Kualitas hidup pasien pasca intervensi koroner perkutan', Jurnal Keperawatan Padjajaran, 2(1), pp. 22-27. doi: 10.24198/jkp.v2i1.77.

Koesmanto, S., \& Novandhori, D. R. (2013) 'Hubungan peran keluarga dengan kualitas hidup lansia yang mengalami gangguan fungsi kognitif di desa Windunegara Kecamatan Wangon Kabupaten Banyumas', Purwokerto: Universitas Jendral Soedirman.

Lewis, S. L., Dirksen, S. R., Heitkemper, M. M., \& Bucher, L. (2014) Medicalsurgical nursing: Assessment and management of clinical problems (9th ed.). Missouri: Elsevier Mosby.

Peric, V., Jovanovic-Markovic, S., Peric, D., Rasic, D., Novakovic, T., Dejanovic, B., \& Borzanovic, M. (2015) 'Quality of life in patients of different age groups before and after Coronary Artery By-Pass Surgery', Ann Thoracic Cardiovascular Surgical, pp. 474-480. doi: 10.5761/atcs.oa.1500041.

Rosidawati, I. (2016) 'Kualitas hidup pasien pasca Bedah Pintas Arteri Koroner (BPAK)', Universitas Muhammadiyah Tasikmalaya.

Williams, L. S., \& Hopper, P. D. (2007) 
Understanding medical surgical nursing. Philadelphia: F.A Davis.

World Health Organization (WHO) (2014a) Noncommunicable Diseases (NCD) Country Profiles, Vienna: World Health Organization.

World Health Organization (WHO) (2014b) 'The world health organization quality of life (whoqol)-bref', Vienna: World Health Organization.

Wulandari, P. H. (2017) 'Perbandingan komplikasi mayor cabg dan pci pada pasien coronary artery disease di RSUD Dr Soetomo Surabaya Periode 2014-2015 (Doctoral dissertation, Universitas Airlangga)'. 